\title{
Emakumeen emozio-zurrunbiloa erditzean
}

\section{(Emotional whirlwind of women in childbirth)}

\author{
Beatriz Pereda-Goikoetxea*1, María Isabel Elorza-Puyadena ${ }^{1}$, \\ Mikel Lersundi-Ayestaran ${ }^{2}$, Joseba Xabier Huitzi-Egilegor ${ }^{1}$, \\ María José Uranga-Iturrioz ${ }^{1}$, Blanca Marín-Fernández ${ }^{3}$
}

${ }^{1}$ Erizaintza II Saila, Medikuntza eta Erizaintza Fakultatea. Donostiako Atala (UPV/EHU) ${ }^{2}$ Euskal Hizkuntza eta Komunikazioa Saila, Medikuntza eta Erizaintza Fakultatea.

Donostiako Atala (UPV/EHU)

${ }^{3}$ Osasun Zientzien Departamentua, Nafarroako Unibertsitate Publikoa (UPNA), Iruña

LABURPENA: Erditzea prozesu indibidual eta konplexua da, emakume bakoitzaren bizitzan mugarri dena. Erditze-gertaeran prozesu fisiologikoen eta psikologikoen arteko erlazioa gertatzen da, emakumearen, semearen edo alabaren ongizatean eta amaren eta bikotearen arteko harremanean eragina izan dezaketen gizarte-, ingurumen-, antolamendu- eta politika-testuinguruek eraginda. Gaur egungo osasun-paradigmen bidez sustatzen da erabiltzaileek eta osasun-profesionalek beren bizipenen alderdi positiboei eta negatiboei buruzko ikuspegia eta gogoetak adieraztea. Beraz, lan honetan aztertuko dira amek ospitaleko erditzean positibotzat edo negatibotzat hartzen dituzten esperientziak eta izandako emozioak eta sentimenduak. Emaitzak funtsezkoak dira erditzean emakumearengan zentratutako zaintza modu indibidualizatuan, pertsonalizatuan, holistikoan eta jarraituan bideratu ahal izateko, emakumearen balioak, aukerak, kultura eta emakumearen eta bikotekidearen nahiak errespetatuz.

HITZ GAKOAK: emakumeen esperientziak, emozioak, erditzea, ikerketa kualitatiboa, sentimenduak.

ABSTRACT: Childbirth is an individual and complex process that represents a milestone in every woman's life. The birth episode involves a relationship between physiological and psychological processes influenced by social, environmental, organisational, and political contexts that may affect the well-being of the woman, the child and the relationship between the mother and the partner. Current health paradigms encourage users and health professionals to express their vision and reflections about the positive and negative aspects of their experiences. Therefore, this paper will analyse the experiences, emotions and feelings that mothers perceive as positive or negative in hospital birth. The results are essential for the delivery of woman-centred care in an individualized, personalized, holistic and continuous provision of woman-centred care in childbirth, respecting the values, opportunities, culture and wishes of the woman and the partner.

KEYWORDS: childbirth, emotions, feelings, qualitative research, women's experiences.

\footnotetext{
* Harremanetan jartzeko / Corresponding author: Beatriz, Pereda Goikoetxea. Erizaintza II Saila, Medikuntza eta Erizaintza Fakultatea. Donostiako Atala (UPV/EHU). - beatriz.pereda@ehu.eus - https://orcid.org/0000-0001-8441-5884

Nola aipatu / How to cite: Pereda-Goikoetxea, Beatriz; Elorza-Puyadena, María Isabel; Lersundi-Ayestaran, Mikel; Huitzi-Egilegor, Joseba Xabier; Uranga-Iturrioz, María José; Marín-Fernández, Blanca (2021). "Emakumeen emozio-zurrunbiloa erditzean». Ekaia, 41, 2021, 31-48. (https://doi.org/10.1387/ekaia.22511).

Jasotze-data: 2021, urtarrilak 31; Onartze-data: 2021, maiatzak 25.

ISSN 0214-9753 - eISSN 2444-3581 / (c) 2021 UPV/EHU
}

cc)(i) $\Theta$ Lan hau Creative Commons Aitortu-EzKomertziala-LanEratorririkGabe 4.0 Nazioartekoa lizentzia baten mende dago 


\section{SARRERA}

Emakume bakoitzarentzat bizitzan mugarritzat hartzen den esperientzia konplexu eta ahaztezina da erditzea. Larkinek, Begleyk eta Devanek [1,2] diote erditzea interrelazioan dauden prozesu fisiologiko eta psikologiko subjektiboz osatutako gertaera dela. Esperientzia honetan gizarteak, ingurumenak, antolaketak eta testuinguru politikoak eragin zuzena dute, bai amaren eta jaioberriaren artean, bai amaren eta bikotekidearen arteko erlazioan [3].

Emakumeek bizitza osoan dute gogoan erditzearen esperientzia [4, 5]. Esperientzia hori ona bada, amatasunarekiko eta jaioberriarekiko jarrera positiboarekin erlazionatzen da [6]. Aldiz, negatiboa bada, lotzen da trauma osteko estresarekin, erditze ondorengo depresioarekin [7], hurrengo haurdunaldietan depresioa jasateko arriskuarekin [8] eta zesarea aukeratzeko eskaera handiagoarekin [9], eta horiek etorkizuneko ugalketetako erabakietarako transzendenteak [5] izan daitezke.

Azken ikerketek erditze-esperientziaren bizipen positiboan edo negatiboan eragina izan dezaketen hainbat faktore aztertu dituzte, hala nola, informazioaren komunikazioa [10], zaintzaileekiko harremana [11-13], erabakiak hartzeko parte hartzea [14] eta kontrol-sentsazioa [15]. Faktore horiei lotuta, sentimendu negatiboak ikerlan ugaritan aztertu dira, hala nola, beldurrak [16-18] eta erditzeak eragindako trauma psikologikoa [7, 19]. Baina sentimendu positiboen ikerketetan gabezia dago.

Hori guztia kontuan hartuta, lan honen helburu nagusia izango da amek ospitaleko erditzean positibotzat edo negatibotzat hartzen dituzten esperientziak eta izandako emozioak eta sentimenduak deskribatzea, erditze idealaren definiziora hurbildu nahian. Emaitzak funtsezkoak dira erditzean zaintza modu indibidualizatuan, pertsonalizatuan, holistikoan eta jarraituan egin ahal izateko.

Lana egin ahal izateko ikuspuntu fenomenologikoa duen ikerketa kualitatiboa erabili da, eta Donostiako Unibertsitate Ospitalean egin da.

\section{METODOLOGIA}

Ikerketa kualitatiboaren izaerak diseinu induktiboa, irekia, malgua eta ziklikoa dakar berekin. Sortzen ari den eran, moldatuz doa eta ikertzen ari den eta bakarra ez den errealitatearen ezagutza sorrarazten du [20]. Errealitatea denboran zehar egoeraren eta testuinguruaren arabera aldatuz doanez, desberdina da pertsonaz pertsona [21]. Horregatik, ikerketa honetan parte hartu duen emakume bakoitzak erditzeari eman dion esanahia kontuan izanez, prozesuaren fenomenoa aztertu da haren testuinguru naturalean. 


\subsection{Laginketa mota: tamaina eta lagin-bilketa}

Lan honen helburua ez da adierazgarritasun estatistikoa lortzea [22], baizik eta, informatzaile onak izanez, errealitatea modu zabalenean eta egokienean islatzea. Errealitate hau lortzeko laginketa moldatuz joan da, jasotzen eta sortzen ziren datuen arabera [23]. Horretarako, laginketa intentzionala eta teorikoa erabili dira, apropos bilatuz eta aukeratuz aurrez pentsatutako ezaugarriak betetzen dituzten emakumeak, diskurtsoaren bidez errealitatearen aldakortasuna irudikatuko dutelakoan.

Lehenengo gerturatzea, erditze-erregistroak erabiliz, komenigarritasunez eta oportunitatez egin da [24]. Gainera, bikote batek borondatez eskaini du bere burua elkarrizketarako. Jarraitu diren irizpideak 1. taulan agertzen dira.

1. taula. Emakumeak barneratzeko erabilitako irizpideak.

\begin{tabular}{ll}
\hline \multicolumn{1}{c}{ Aldagai orokorrak } & \multicolumn{1}{c}{ Aldagai zehatzak } \\
\hline - Hizkuntza & - Euskara edo gaztelania ulertzeko gaitasuna \\
- Adina & -18 urte edo gehiago duten emakumeak \\
- Konpetentzia & - Baimen informatua ulertzeko eta izenpetzeko konpetentea \\
- Fetuaren aurkezpena & - Buruzko aurkezpena \\
- Jaiotza & - Jaioberri bizia \\
- Haurdunaldi-asteak & - Haurdunaldia 37 aste edo gehiago \\
\hline
\end{tabular}

Egileek landua.

Emakumeak Donostiako Unibertsitate Ospitaleko erdiberriaren unitatean atzeman ziren, erditu ondoren 48 ordu pasa eta gero. Orduan, bai ahoz eta bai idatziz ikerketaren berri eman zitzaien. Horrekin batera, baimen informatua banatu zitzaien izenpetu ahal izateko, eta erabaki zen kontaktua noiz eta nola izango zen. Momentu berean galdeketa soziodemografikoobstetrikoa egin zen parte-hartzaileen ezaugarriak identifikatzeko.

Parte-hartzaileak aukeratzekoan kontuan hartutako aldagaiak honako hauek izan dira: erditzearen hasiera eta bukaera, emakumeak izan dituen haurdunaldiak, analgesiaren erabilera eta jaioberriaren egoera (2. taula).

2. taula. Laginketa teorikoan aukeraketa estrategikoa egiteko erabili diren aldagaiak.

\begin{tabular}{l|llllll}
\hline \multicolumn{6}{c}{ Erditze prozesua } \\
\hline \multirow{2}{*}{ Aldagaiak } & $\begin{array}{l}\text { Hasiera } \\
\text { mota }\end{array}$ & Bukaera mota & $\begin{array}{l}\text { Haurdunaldi- } \\
\text { kopurua }\end{array}$ & $\begin{array}{l}\text { Analgesiaren } \\
\text { erabilera }\end{array}$ & $\begin{array}{l}\text { Jaioberriaren } \\
\text { ospitaleratzea }\end{array}$ \\
\cline { 3 - 6 } & Dimentsioak & $\begin{array}{l}\text { Bere kasa } \\
\text { Eragindakoa }\end{array}$ & $\begin{array}{l}\text { Berezkoa } \\
\text { Instrumentala } \\
\text { Zesarea }\end{array}$ & $\begin{array}{l}\text { Lehenerdia } \\
\text { Multiparoa }\end{array}$ & $\begin{array}{l}\text { Bat ere ez } \\
\text { Lokala } \\
\text { Epidurala } \\
\text { Intradurala }\end{array}$ & $\begin{array}{l}\text { Bai } \\
\text { Ez }\end{array}$ \\
& & & & & \\
\hline
\end{tabular}

Egileek landua. 
Laginaren tamaina 42 emakumez eta bikote batez osatua geratu da.

Ikerketako galderei erantzun nahian, garapen analitiko-interpretatiboa, hau da, aukeraketa sekuentzialeko laginketa teorikoa etengabeko interpretazioan oinarrituta landu da.

Diskurtsoaren analisia egin ondoren, informazioa errepikatu denean, edo/eta jasotako informazioak ez dienean ikerketen galderei erantzuten [24], partaide berri gehiago ez bilatzea erabaki da.

Datuak jaso ahal izateko, Vallés-ek [25] proposatutako teknikak erabili ohi dira: elkarrizketarena, parte-hartuzko behaketarena eta dokumentazioarena.

Elkarrizketak erdiegituratuak izan dira, eta haurra izan duten emakumeekin izan dira bi aldiz: erditu eta 8 astera eta erditu eta 8 hilabetera; kasu bat kenduta beste guztietan grabatu egin dira, parte-hartzaileen baimenarekin. Elkarrizketetan erabilitako hasierako gida tematikoa eta haren egokitzapena 3. taulan jarri dira.

3. taula. Elkarrizketetan hasierako gida tematikoa eta haren egokitzapena.

\begin{tabular}{|c|c|c|c|}
\hline \multicolumn{2}{|c|}{ Hasierako gida tematikoa } & \multicolumn{2}{|c|}{ Gida tematikoaren egokitzapena } \\
\hline $\begin{array}{l}\text { Galdera } \\
\text { nagusia }\end{array}$ & $\begin{array}{l}\text { - Nolakoa izan da zure er- } \\
\text { ditze esperientzia? (8 as- } \\
\text { tera) } \\
\text { - Zer gogoratzen duzu zortzi } \\
\text { hilabeteren ondoren zure } \\
\text { erditze-esperientziaz? }\end{array}$ & $\begin{array}{l}\text { Galdera } \\
\text { nagusia }\end{array}$ & $\begin{array}{l}\text { - Hasierako gida tematiko- } \\
\text { koak }\end{array}$ \\
\hline Itxaropenak & $\begin{array}{l}\text { - Nolakoa da zuretzat erdi- } \\
\text { tze ideala? }\end{array}$ & Itxaropenak & $\begin{array}{l}\text { - Nolakoa da zuretzat erdi- } \\
\text { tze ideala? } \\
\text { — Nola espero zenuen zure } \\
\text { erditze esperientzia? }\end{array}$ \\
\hline Emozioak & $\begin{array}{l}\text { - Zer emozio eta senti- } \\
\text { mendu sentitu zenituen } \\
\text { erditzean? }\end{array}$ & Emozioak & $\begin{array}{l}\text { - Hasierako gida tematiko- } \\
\text { koa }\end{array}$ \\
\hline Oroitzapena & $\begin{array}{l}\text { - Zeintzuk dira zure erdi- } \\
\text { tzeko oroitzapen onenak } \\
\text { eta txarrenak? }\end{array}$ & Oroitzapena & $\begin{array}{l}\text { - Zeintzuk dira zure erdi- } \\
\text { tzeko oroitzapen onenak } \\
\text { eta txarrenak? } \\
\text { - Zer aldatuko zenuke zure } \\
\text { erditzean? } \\
\text { - Zein da erditzearen ingu- } \\
\text { ruan gogoratzen duzun } \\
\text { lehenengo gauza? }\end{array}$ \\
\hline
\end{tabular}

Egileek landua. 
Parte-hartuzko behaketa erditze lekuan bertan egin da, kontuan izanez ikertzaileak ezin zuela inola ere erditzearen prozesuan eraginik izan, eta taldeko bat gehiago zela; era horretan, profesionalen eta emakumeen arteko elkarreraginak eta portaerak azter zitezkeen.

Dokumentazio-teknika lan-egunkaria erabiliz egin da, erabaki metodologikoak eta analitikoak antolatzeko.

\subsection{Datuen analisia eta interpretazioa}

Datu guztiak 2016ko maiatzetik 2017ko maiatzera arte jaso dira. Prozesu honetan eta datuen analisian, interpretazioan eta idaztean gogoetaprozesuaren ariketa etengabea egin zen, Gadamerrek, Hollowayen eta Galvinen [26] Qualitative Research in Nursing and Healthcare liburuan, dioen moduan, aurreiritziak barneratuz. Ikertzailearen papera objektiboa izateko asmoz, ikerketa honetan parte-hartzaileekin lortutako harremana, erreakzioak, sentimenduak eta eragozpenak gainbegiratuz, gogoeta kritikoa etengabekoa eta kontzientea izan da [21, 26]; bera, ikertzailea, ikertutako fenomenoaren parte izan da.

Lortutako informazio guztia era sakonean ulertu ahal izateko, eta ikerketaren galderei erantzuna emateko ATLAS.ti 7 programa informatikoa erabili da. Analisi tematikoa egitean jarraitu diren faseak 4. taulan agertzen dira.

4. taula. Datuen analisi tematikoaren faseak.

Analisi tematikoaren faseak

- Grabazioen hitzez hitzeko transkripzioa. Irakurtzea eta berrirakurtzea

- Aipuetan testuaren aurrekodifikazioa

- Kodifikazio substantiboa eta gero kontzeptuala

- Honako hauen etengabeko elkarrekintza: aipu-aipuak, kode-kodeak eta hausnarketen idatz-oharrak

- Sortutako kategoriak, taulak erabiliz ordenatzea

- Kategoriak eta gaiak sareen bidez alderatzea

- Gainerako ikertzaileekin partekatzea eta eztabaidatzea

- Fenomenoaren deskribapena

Egileek landua.

Era berean, kalitateko irizpideak ziurtatzeko Calderon-ek [27] ikerketa kualitatiborako proposatutako puntuak hartu dira oinarritzat: doikuntza epistemologikoa eta metodologikoa, adierazgarritasuna, baliotasuna eta etengabeko gogoeta kritikoa. 
Doikuntza epistemologikoa eta metodologikoa ziurtatzeko prozedurak honako hauek izan dira: ikertzailearen rola identifikatu; dokumentazioa erabili, emaitzak beste batzuekin erkatzeko; laginketa marko kontzeptualari moldatu; eta ikerketa-galderak eta laginketaren estrategia moldatuz joan, informazio garrantzitsuena lortu eta erabili ahal izateko.

Adierazgarritasuna demostra daiteke lortutako informazioa aplikagarria izan delako ospitalean eta lehen mailako arreta-zentroetan. Era berean, lagungarria izan daiteke beste ospitale batzuetarako ere.

Baliotasuna ziurtatzeko, grabazio eta transkripzio literalak egin dira, eta informazioa parte-hartzaileekin kontrastatu da ikerketaren fase guztietan; bukaeran informazio osoa igorri zaie.

Ikertzaile nagusia, emagina denez, etengabeko autogogoetan oinarritu da, izandako esperientziak eta hasierako planteamenduak nola eragin zezaketen kuestionatuz. Autogogoetaren irizpidea bermatzeko erabili diren teknikak honako hauek izan dira: lan-egunkaria, konfiantzazko harremana eta datuak beste ikertzaileekin triangulatzea. Saturazioa datuak behin eta berriro errepikatzen hasi direnean hartu da kontuan.

\subsection{Baimen etikoak}

Ikerketa hasi aurretik Gipuzkoako Ikerketa Klinikorako Osasun arloko Batzorde etikoaren baimena lortu da (erreferentzia: BPG-APH-2015-01).

Datuen erabileran konfidentzialtasuna eta anonimotasuna zorrotz zaindu dira, informazioa kodeen bitartez kudeatuz. Grabazioak UPV/ EHUko Medikuntza eta Erizaintza Fakultateko artxibo kodifikatu batean gorde dira.

\section{ERDITZEAN BIZITAKO EMOZIOAK ETA SENTIMENDUAK}

Emozioz hitz egiten denean, erreferentzia egiten zaie pertsonek, aldaketei edo estimulu berriei berezko edo ikasitako moldaketa erantzunak emateko, sortzen dituzten erreakzio fisiologikoei eta psikologikoei. Sentimenduak, aldiz, emozioaren emaitzak dira, hitzez adieraz daitezke eta denboran askoz ere gehiago irauten dute.

Egindako ikerketa honetan, emakumeek erakutsitako emozioak eta sentimenduak ugari izan dira, eta, 1. irudian ikusten den moduan, denak elkarreraginean haize-emaile edo sare moduan antola daitezke. 


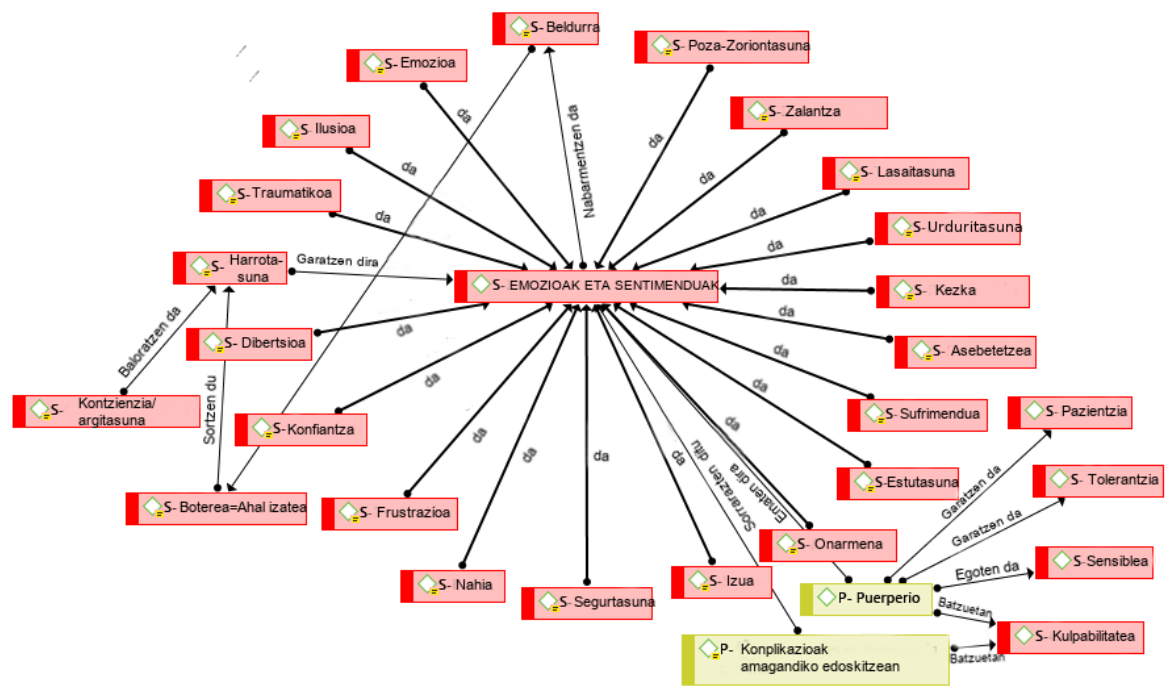

1.irudia. Erditzean bizitako emozioen sarea. Egileek egina Atlas. ti 7 erabiliz.

Emozio nahasiak eta, era berean, osagarriak (zalantza-beldurra) edo kontraesanak (lasaitasuna-urduritasuna, poza-kezka-satisfakzioa) oso adierazgarriak dira emakumeen kontaeren artean.

«Zalantza bai, beldurrarekin. Nik mingarria izango zela uste nuen, ezezagunari izaten zaion beldurra.» $38 \mathrm{M}-\mathrm{A}$ (75:32)

«Ilusioa eta poza bazetorrelako, baina, aldi berean, kezka eta urduritasuna nola irtengo ote zen pentsatuz.» $21 \mathrm{M}-\mathrm{A}(41: 34)$

«Lasai nengoen, baina, era berean, urduri, ikusteko desiratzen.» 24 M-B (117:30)

Deskribatutako beste sentimendu batzuen artean, sufrimendua, estutasuna, onarmena, ikara, ziurtasuna, nahia, frustrazioa, konfiantza, dibertsioa... Hauek guztiek, nahastuta, erditzearen konplexutasuna eta bizitasuna adierazteaz gain, emakume bakoitzaren bakoiztasuna ere erakusten dute, eta, era berean, ekintza desberdinak bilatzeko eta egiteko indarra. Ekintza hauen artean, autonomia eta erabakitzeko gaitasuna sentituz, azpimarratu daitezke egiten diren ahaleginak informazioa lortzeko, atentzio egokia bilatzeko eta bakoitzaren beharren eta itxaropenen arabera ekarpenak egiteko. 


\section{Emakumeek adierazten dituzten emozio} eta sentimendu nabarmenenak

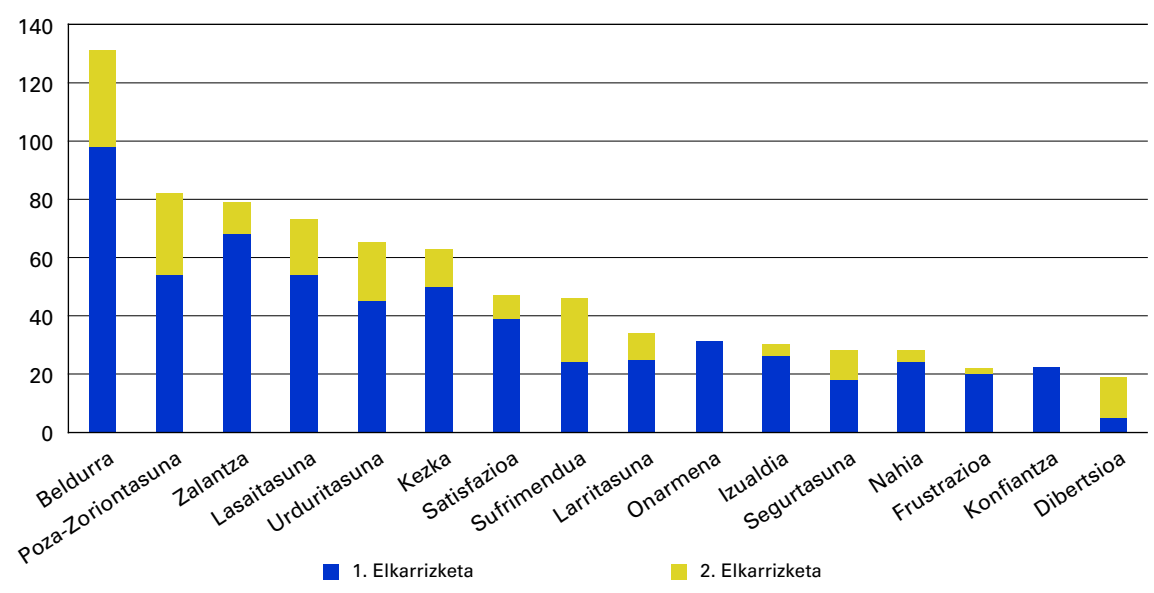

2. irudia. Gehien izendatutako emozio eta sentimenduak erditu eta 8 astera, eta 8 hilabeteren ondoren. Egileek landutako grafikoa.

Azaldutako emozioak askotan ustekabekoak eta kontrolaezinak izan badira ere, emakumeek erditzeari buruz zituzten itxaropenei eta aurreiritziei erantzuna ematen diete. Askotan lotzen dituzte segurtasunarekin, iraupenarekin, minaren mailarekin edo kontrolarekin, erditzearen hasieran edo bukaeran beharko liratekeen interbentzioekin, edo ondorengo garapen puerperalarekin.

Oro har, espektatiben arabera emakumeen emozioak hiru arlotan sailka daitezke:

- Zituzten itxaropenak bete ez zituzten emakumeak.

- Espero zutena bete edo gainditu zuten emakumeak.

- Espektatibarik markatu gabe etorri ziren emakumeak.

Lehenengo taldean, itxaropenak bete ez zituzten emakumeen artean, nabarmenak izan dira frustrazioa, tristura, emozio falta eta dezepzioa.

«Hasieran ondo, ikusteko desiratzen, baina gero, hain nekatuta nengoenez, ezin nuen ezta hartu ere. Pentsatzen nuen momentu polita izango zela baina, azkenean, ez zen horrela izan.» 34 M-A (67:20)

«Nik dena naturala nahi nuen eta guztiz kontrakoa izan zen... eta gero haurra iritsi zen eta ni hain nengoen nekatuta, ez bainengoen emozionatuta, eta ez nuen ezer sentitzen.» (14:3-6)

Bigarren taldean, espero zutena bete edo gainditu zuten emakumeek, poza, harrotasuna, eta gozamena adierazi dute: 
«Neretzat, bizitzako momentu pozgarrienak nire lau erditzeak izan dira; miragarria iruditzen zait.»12 M-B (121:1)

«Esperientzia sinestezina da: nola egin dezakegu pertsonek horrelako bat? Poza, poz handia.» 38 M-B (138:14)

Espektatibarik markatu gabe etorri ziren emakumeen taldeak jarrera irekia erakutsi zuen erditze-prozesu osoan dezepzio-sentsazioa ez jasateko:

«Nik ez nuen ezer espero, pelikula eginda eraman izanez gero, ustekabea jasotzeko arriskua duzu.» 28 M-B (125:8)

«Iritzi batekin bazoaz, baginako erditzea, adibidez, eta gero zesarea suertatzen bada atsekabetuta geratzen zara, beharrezkoa izanda ere.» 4 M-A (8:67)

Kasu guztietan aurrez espero zena, izaera kognitiboa duen aldagaia denez, baliagarria da momentuko pertzepzioak, pilatutako aurresperientziak, kanpoko eta barneko inpresioak eta informazioak erkatzeko, eta bakoitza bizitzen ari den egoera dinamikoa etengabe berrantolatu ahal izateko.

Emakumeek zurrunbilo emozionala adierazten dute beren erditze-prozesuaren oroimenean, eta zurrunbilo hori erabat baldintzatzen dute beharrak asetzeko moduak, itxaropenek, erditze-prozesuaren bilakaerak eta jaio ondoko egokitzapen-prozesuak.

\subsection{Beldurra: emozio ohikoena}

Aurreko irudian (2. irudia) ikusten den moduan, emakumeek sentimendu aldakorren nahasketa deskribatu badute ere, gehien errepikatu dena beldurra izan da. Beldurra izan da lehengo, oraingo edo ondorengo arrisku errealen edo ustezkoen ondorioa izan daitekeen estutasunak edo konfiantza ezak eragindako sentsazioa.

«Minak, batez ere, beldurra ematen zidan, urduritasuna eta beldurra.» 31 M-A (61:19)

«Beldurra dena ondo joango ote zen edo ez, kezka hori.» $40 \mathrm{M}-\mathrm{B}$ $(143: 10)$

Beldurraren arrazoi nagusietakoa erditzearen bilakaerarekin eta amaierarekin lotzen dute, era instrumentalean edo zesarearekin bukatuko ote zen kezkarekin. Hala ere, erditzeak aurreikusia zutenarekin bat egin bazuen, beldurra igarokorra izan zen.

«Dena ondo irtengo ote zen beldurra, eta beste bat instrumentala izango ote zen.» $42 \mathrm{M}-\mathrm{A}(83: 62)$ 
«Beldur pixka bat pasa nuen luzea egiten ari zelako, eta zesarearekin bukatzeak beldurra ematen zidan.» $31 \mathrm{M}-\mathrm{B}(121: 14)$

Baina beldurra, batez ere, haurrak izan zitzakeen arazoekin lotzen dute. Amek behin eta berriro errepikatu dute beldurra zutela umearen egoeragatik, eta konplikaziorik gabe jaiotzearen nahia adierazi dute.

«Beldur handiena neskatila ondo ez egoteak ematen zidan.» $40 \mathrm{M}-\mathrm{A}$ (79:25)

«Batez ere, neskatila erditzean sufrimendurik gabe jaio dadila.» 31 M-A (61:8)

Haurrak arazoak bazituen, umearengandik banatzea ekar zezakeen, eta horregatik ere, emakumeek beldurra adierazi dute. Banatzea, bi alderditatik deskribatzen dute: alde batetik, semea edo alaba jaio ondoren zerbitzu berezi batera eraman behar izatea, eta beste aldetik, jaioberria ospitalean geratu behar izatea amari alta eman ondoren. Umea ospitalean geratu beharreko esperientzia guztiz eramangaitza dela kontatu dute, eta gainera, kontrolaezina, haurra abandonatuko bazenu bezalakoa.

«Gainean jarri zidaten, baina ez zuen arnasarik hartzen, eta eraman egin zuten, eta beldur handia sartzen da orduan.» 35 M-A (69:3)

«Etxera umerik gabe... nire errotik kendu zidatelako irudia nuen.» 35 M-A (69:46)

\subsection{Sufrimendua, larritasuna, onarmena: dilatazioan eta egozte-fasean minarekin gehien lotzen diren emozioak}

Sufrimenduaren eta minaren pertzepzioan emakumeen gogo-aldarteak, aurresperientziak, itxaropenak eta aldez aurretik pentsatuta zituzten helburuak baldintza izan dira, eta norberaren konfiantza, konfiantza eza edo hurrengoetarako erabaki erreproduktiboak erakutsi dituzten sentsazioak markatu dituzte.

«Mina ez da ahazten, ikaragarria delako, baina berriro ere pasako nuke.» $15 \mathrm{M}-\mathrm{A}(30: 37)$

«Kontrakzioak oso gogorrak izan ziren. Nik senarrari esaten nion: hau lehenbizikoa izan balitz ez nuen besterik izango.» 17 M-A (34:26)

Sentsazioen artean, emakumeek negatibo gisa nabarmentzen dituzte mina eta sufrimendua uzkurtze-garaian. Min guztietan bezalaxe, minaren subjektibotasuna eta aldakortasuna aipa daitezke, emakume bakoitzak dituen faktoreak eta ezaugarriak minaren pertzepzioan eragin zuzena dutelako. 
Faktore horien ezaugarrien artean dimentsio fisiologikoa eta sentsitiboa nabarmentzen dira: minaren lokalizazioa (sabelaldekoa, perineokoa, gerrialdekoa), hasiera (bafatzekoa-pixkanakakoa), iraupena (luzea-motza), intentsitatea (txikia-erdia-handia), ezintasun-maila (txikia-erdizkakoa-osoa), erritmoa, sarritasuna, eta abar.

«Kontrakzioak oso-oso mingarriak izan ziren. Nire bizitzako okerretzat gogoratzen dut.» $20 \mathrm{M}-\mathrm{A}(39: 3)$

«Nik pentsatzen nuen aldakako hezurrak puskatuko zitzaizkidala; ikasitako arnasketak ez zuen ezertako balio.»14 M-A (28:52)

Minak baldintzatuta, mugikortasunarekin, atseden beharrarekin edo komunikazioarekin erlazionatuta, patroi eta erreakzio desberdinak bereiz daitezke. Erreakzio desberdinen artean badaude era aktiboan parte hartu duten emakumeenak, eta, eginkizuna neurri handi batean profesionalen esku utziz, jarrera hain aktiboa hartu ez dutenenak.

Minaren tolerantziak sortutako patroien artean esan daiteke batzuek barne kontrola galdu zutelako sentsazioa azpimarratu dutela; paperak galdu zituztela nabarmentzen dute, eta kontrol falta horrek autonomia eza eta erabakiak hartzeko gaitasuna galarazi ziela. Horiek guztiak, gehienetan, mugimendu kontrolaezinarekin eta dena garrasi bidez kanporatzearekin lotzen dituzte.

«Erabat deskontrolatua, «baina zer da hau?» esaten duzu. Ezin duzu hitz egin, ezta negar egin ere; mina, mina leku guztietatik, garrasi egin?...»18 M-A (36:14) (39:36)

«Nik paperak galdu nituen, mina ikaragarria izan zen eta.» $20 \mathrm{M}-\mathrm{A}$

Beste batzuek, aldiz, gorputzaren eta buruaren jabetza izan zutela zioten, eta dena kontrolpean izan zuten.

«Zentzu horretan autokontrola sentitu nuen, nire gorputza ezagutzen nuelako konfiantza. Orduan ongi sentitu nintzen.» $21 \mathrm{M}-\mathrm{B}$ (111:21)

«Pozik erditze honetan parte hartu dudalako, lagundu egin dut eta hori, niretzat, onena izan da.» 27 M-B (53:42)

\subsection{Nahia: erabakitzeko eskubidea izatea}

Nahiaren esanahia guztiz subjektiboa bada ere, behin eta berriro ondo irtetearen itxaropena eta erabakiak hartzeko ahalmenaren ideiak errepikatu ziren. 
Ondo irtetearena ama-haurra binomioaren osasunarekin lotzen bada ere, bikoitza den bidetik hausnar daiteke. Alde batetik, ondo ez egotearen zalantza nagusiak lehen aipatutako beldurrarekin lotuta. Eta bestetik, dena ondo joango den itxaropena eta nahia ildo beretik doaz. Aurreko binomioa beldurraren eta nahiaren arteko dialektika etengabea erakusten duten konstante gisa ikus daiteke.

Erabakiak hartzeko nahia ere behin eta berriro aipatu da, batez ere minik gabeko erditzea bilatu nahian. Horregatik, garrantzi berezia eman zaio analgesia epidurala aukeratzeko edo ez aukeratzeko posibilitatea izateari eta, aldi berean, emakumeak berak erabaki hori hartzea izan da ongien baloratutako premisa.

«Epidurala eskaini zidaten, baina ezetz esan nien ongi nengoelako.» 39 M-A (77:55)

«Epidurala hor zegoen, nik erabakitzen nuenerako. Beraz, askatasun osoa eman zidaten nahi nuenean eskatzeko.» $33 \mathrm{M}-\mathrm{A}$ (65:34)

Gaur egun, esan daiteke ospitalean analgesia epidurala hartzeko edo ez hartzeko emakumeak duen eskubidea dela eta, askatasunez har dezakeela erabakia emakume bakoitzak. Logikoki, erabakia erditzeko minekin lotuta dago, eta hau esperientzia sentsorial eta emozional subjektiboa da.

Analgesia epiduralarekiko subjektibitatearen garrantzia argi geratu da emakumeen iritziak jaso ondoren. Batzuek argi daukate ez zutela inondik inora epiduralik jarri nahi; beste batzuek pentsatzen zuten erditzearen bilakaera ikusita hartuko zutela erabakia; badago epiduralik nahi ez zuenik, baina erditzearen bilakaeragatik jartzea erabaki zuena; beste emakume batzuek hasieratik argi zuten epidurala nahi zutela, mina beharrezkoa ez den eta zentzurik ez duen sufrimendutzat hartu zutelako.

Epiduralik jarri nahi ez duten emakumeek erditze naturalagoarekin lotzen dute prozesua eta euren nahia izan da kontzientzia eta partizipazio handiagoa izatea. Horren bidez eurak estimuluak interpretatzeko gai zirela diote, momentuko egoeraren jabe izan baitira zentzuen bitartez. Argi zeukaten erditzean aktiboak izan nahi zutela eta itxaropen hori zuten aurreikusita.

«...hiruetatik hau izan da bakarra epiduralik gabe,... askoz ere naturalagoa, gogoramen polita geratu zait; min handia bai, baina gomendagarria.» $14 \mathrm{M}-\mathrm{A}(28: 5)$

«Ahal bazen epidurala ez jartzea zen nire nahia, era naturalean egitea erabaki nuen, argi eta aktibo egon nahi nuen.» $14 \mathrm{M}-\mathrm{A}$ (28:5)

Dena den, batzuetan informazio kontrajarriak jasoak zituzten. Ama izandako emakume batzuek epidurala esperientzia positiboa zela esaten 
zieten. Aldiz, beste batzuek esaten zieten ez zutela jaiotzaren sentsazio fisikorik bizi izan. Horregatik, ez dute beti erabakia hartuta ekartzen eta momentuko egoerara moldatzea izan da aukeratutakoa.

Oro har, epidurala jartzea erabaki duten emakumeen artean, esperientzia positibotzat jo dute, batez ere beren erabakia errespetatu delako eta momentu guztietan lagunduta, babestuta eta, era berean, prozesuaren parte sentitu direlako. Hala ere, talde honetan bi alderdi ikus daitezke. Alde batetik, emakume batzuek sentitu duten harridura, epidurala jarri ondoren erditzea sentitu egin zutelako eta ez zutelako hori espero. Horren ondorioz, zuten kulpa sentsazioa desagertuz joan zitzaien eta ez dute damurik izan hartutako erabakiagatik.

«Harrituta nengoen, epiduralarekin mugimenduaren sentsazioa kendu egingo zidatela pentsatzen nuelako, baino ez, ez nuen aurreko minik eta pasatzen ari zena sentitzen nuen.» $14 \mathrm{M}-\mathrm{A}(28: 102)$

Beste aldetik, mina alferrikako sufrimendutzat hartzen zutenak eta analgesia epidurala nahitaezko errekurtsotzat ikusten zutenak erditzean minik ez izateko.

«Iritsi eta epidurala jarri; ni epiduralaren aldekoa naiz.» $36 \mathrm{M}-\mathrm{A}$ (71:30).

Esandakoak esanda ere, «analgesia epidurala bai, analgesia epidurala ez» gai eztabaidagarrienetako bat izan da, arlo sozial kontrajarriak planteatu direlako, hala nola minez erditzeko tradizioari eustea edo rol tradizional hori haustea. Dena dela, norberak aukeratzeko posibilitatea positibotzat baloratu da, eta, oro har, hartutako erabakiarekin emakumea gustura geratu ohi da.

\subsection{Poza, lehenengo ukitua, larruazala-larruazalarekin jartzea: erditzeko eta amatasuneko prozesua gorpuztea}

Emakumeen kontakizunen arabera, momentu erakargarrienetakoa eta era positiboan gehien gogoratzen dena haurra egotzi ondoren amaren gainean jartzekoa izan da, larruazala-larruazalarekin deritzona.

«Nire gogoramen onena haurra gainean jarri zidatenean. Uste dut beti izango dela nik dudan gogoramen positiboena.» 15 M-A (30:22)

«Onena: haurra gainean jartzen dizutenean; buf!, nik uste dut denok esango dugula gauza bera.» 4 M-A (8:35)

Momentu horretan amek bizipen bikoitza azaleratu dute. Alde batetik, erditze-prozesuaren bukaerako poza, betiere haurra eta ama ondo badaude, 
eta beste alde batetik, amatasunaren hasiera. Horrek guztiak emakumeen bizitzan mugarria markatu du: gertaera esanguratsua, ahaztezina, eta abar.

«Nik ez nuen kontzientzia zer pasatuko zen, baina gainean izan nuenean, dena aldatzen da.»13 M-A (26:22)

«Oraindik ere emozionatu egiten naiz, irudi hori ez da behin ere joaten burutik.» $21 \mathrm{M}-\mathrm{B}$ (111:5)

\subsection{Konfiantza eta lasaitasuna: profesionalen informazioarekin eta entzutearekin bat datozen sentimenduak}

Gogobeteko esperientzia adieraztean, emakumeek bi giltzarri adierazi dituzte. Bata, profesionalak emandako informazioa, eta bestea, arreta handiz entzuna sentitzea.

Emakumeek informazio argia, antolatua eta bizi duten egoeraren araberakoa izan dadila eskatzen dute, unean uneko benetako egoera ezagutu nahi dutelako eta pertsonen arteko konfiantza errazten duelako. Hori dela eta, profesionalen eta emakumeen artean sortu diren sentimendu baikorrak lasaitasun- eta segurtasun-iturritzat hartu dituzte.

«Ze lasaitasun ematen zidan dena esplikatuz joan zenean. Luzea izango da, orain hau jarriko dizugu..., orain beste hau nabarituko duzu.» 8 M-A (16:17)

«Dagoenaren informazio egokia ematea eskatzen dut. Oso momentu latzak pasatzen dira mina dagoelako eta ez dakizulako zer gertatuko zaizun.»13M-A (26:27)

«Denbora guztian adieraztea zer ari den pasatzen lasaigarria da, oso garrantzitsua da.» 7 M-B (95:6)

Arreta handiz entzunak izateari dagokionez, emakumeek bereziki alor hau zaintzea eskatu zuten, erditze-momentua oso kritikoa eta gogorra izan daitekeelako. Etengabeko negoziazioa, behar-beharrezkotzat jo dute profesional/emakume-bikote erlazio terapeutikoa sendotu ahal izateko. Era berean, informazioa bakoitzaren nahietara moldatuz, erabakiak hartzeko gaitasuna areagotu egin zela diote.

«Nik entzuna izatea eskatzen dut. Lehenengo erditzea bada ere entzuna izatea nahi dut. Badakit profesionalak gehiago dakiela, baina hala ere, entzutea eskatzen dut. Horrek balio handia du.» 1 M-A (2:49)

Ongi erantzuten ez zaienean, erantzunak argiak ez direnean, galderak erantzunik gabe geratzen direnean edo isiltasunarekin erantzuten denean, 
edo ahozkoa ez den informazioa kezkatzekoa denean, zalantzak edo beldurguneak adierazi dituzte emakumeek, informazioa ez delako behar bezala ematen edo kezkaren aurrean inork ez dielako entzuten.

«Informazioa behar den moduan ematea, itzulinguruak saihestuz, beharrezkoa ikusten dut. Beldurgarria da jendea sartu eta sartu dabilenean, euren artean zurrumurruka, ezer esan gabe.» 29 M-A (57:5)

«Ez nuen oso esperientzia ona izan, batez ere, komunikazio ezagatik. Ez badizkizute ondo argitzen gauzak, segurtasun-gabezia sortzen zaizu. Dena ondo egongo ote da?» 7 M-B (95:8)

Horiek horrela, erlazioaren ezaugarria komunikazio desegokia izan denean, profesionalek tratu inperatiboaren bidez autoritate osoa erakusten dutenean, emakumeen eta bikotekidearen iritziak zein diren esaten utzi ez zaienean, edo emakumeen pentsaerekiko jarrera kontrajarriak inposatu direnean, erditze-prozesua ezkortzat hartu da, eta berdintasuna eta errespetua eskatu dira.

Oro har, emakumeek mezu argiak eta bateratuak eskatu dituzte, batez ere tentsio-momentuetan, orduan ez zutelako argi bat ote zetorren ikasita ekarri zutena esaten ari zitzaienarekin. Emakumeek laguntza eta ulermena eskatu diete profesionalei, erditze bakoitza ordura arte bizi ez den prozesu bakarra eta berezia delako.

Ospitaleko erditze bakoitzaren ondoren emakume bakoitzak emozio desberdinak deskribatu ditu espektatibak, beharren asetasun mailaren eta erditu ondorengo moldaketan bizi izandakoaren arabera. Horrek guztiak lan honetan metaforikoki emozioen eta sentimenduen zurrunbiloa esan izan diogun esperientzia markatzen du.

\section{EZTABAIDA}

Emakumeentzako emozio eta sentimendu nabarmenena beldurra izan da. Emozio hori sortzen da seme-alabek paira ditzaketen konplikazioekin, erditzean kontrolaren galerarekin, erditze-amaiera motarekin, segurtasunarekin eta erditzean zer gertatuko den ez jakitearekin. Hori bat dator Dencker et al.ek [28] ondorioztatzen dituzten bi planteamendurekin: bata, erditzearekiko beldurra etiketa orokor gisa erabiltzen dela, eta, bestea, depresioak eta gizarte-babes ezak eragiten duela beldurra. Beste ikertzaile batzuek [16] beldurra zaintzaileekiko harremanen kalitate ezarekin lotzen dute.

Rilby et al. [29] ikertzaileek erditzean sentimendu nahasketa identifikatzen dute, adibidez, beldurra eta gozamena. Sentimendu kontrajarri hauek, 
emakumeek ere deskribatu dituzte, hautabide etengabea planteatzen baitute. Autonomia eta erditzean parte aktiboa izateko beharra adierazten dute, baina horrek zerbait ondo aterako ez ote den kezka sorrarazten die. Sheen eta Slade-k $[18,30]$ ondorioztatu duten moduan, emakumeek ez dute beren burua seguru ikusten eta zalantzan jartzen dute erditzean erabakitzeko duten gaitasuna.

Ikerketa honetako emakumeek, protagonista sentitu direnean, segurtasun- eta lasaitasun-sentsazioa eta laguntza-harremanekiko konfiantza sentimendu positiboekin lotzen dituzte. Karström et al.ek [31] ere ideia bera ondorioztatzen dute. Ildo beretik, Hosseini et al.ek [6] erditze positiboa izan duten emakumeek autoestimua eta autokonfiantza hobetu dutela diote. Era berean, emakumeek portaeren eta emozioen kontrola segurtasun pertsonalarekin lotu dute, askotan profesionalekiko konfiantzan eta aukera informatuan oinarrituta [32].

\section{ONDORIOAK}

Emakumeek zurrunbilo emozionala adierazten dute beren erditze-prozesuaren oroimenean. Emozio eta sentimendu aipatuenak honako hauek izan dira: beldurra, poza edo zoriontasuna, zalantza, lasaitasuna, urduritasuna, kezka, satisfakzioa, sufrimendua, nahigabea, onarmena, sustoa, segurtasuna, frustrazioa, nahia, konfiantza eta dibertsioa.

Emakume bakoitzak erditzearen ondoren emozioen eta sentimenduen berezko konbinazioa gogoratzen du, bere beharrak asetzeko moduek, markatutako itxaropenek, erditze-prozesuaren bilakaerak eta jaio ondorengo egokitzapenak baldintzatuta.

Emakumeek erditze-esperientzia positiboa dela definitu dute espektatiba pertsonalak, bikotearenak eta soziokulturalak bete direnean, eta sentimendu eta ekintza baikorren bidez adierazteko gai direnean. Aldiz, esperientzia negatiboa ezintasunaren sentimenduek, beldurrek edo profesionalekin izandako erlazio desegokiek markatzen dute.

Erditze ideala desberdina da emakume bakoitzarentzat, baina, oro har, honako ezaugarri hauekin lotu dute: konplikaziorik ez sortzea, beharrezkoak ez diren interbentzioak ez egitea, informazio egokiarekin hartzen diren erabakietan oinarritzea eta segurtasunaren barnean gertatzea.

\section{BIBLIOGRAFIA}

[1] Larkin, P., Begley, C. M., Devane, D. 2012. «"Not enough people to look after you": An exploration of women's experiences of childbirth in the Republic of Ireland». Midwifery, 28, 98-105. 
[2] Larkin, P., Begley, C. M., Devane, D. 2009. «Women's experiences of labour and birth: an evolutionary concept analysis». Midwifery, 25, e-49-e-59.

[3] BAyrami, R., VAlizadeh, L., ZAHERI, F. 2011. «Nulliparous women's childbirth experiences:a phenomenological study». Medical Journal of Tabriz University of Medical Sciences, 33, 14-19.

[4] Simkin, P. 1991. «Just Another Day in a Woman's Life? Women's LongTerm Perceptions of Their First Birth Experience. Part I». Birth, 18, 203210 .

[5] WaLdENSTRÖM, U. 2004. «Why do some women change their opinion about childbirth over time?». Birth, 31, 102-107.

[6] Hosseini Tabaghdehi, M., Keramat, A., Kolahdozan, S., Shahhosseini, Z., Moosazadeh, M., Motaghi, Z. 2020. «Positive childbirth experience: A qualitative study». Nursing Open, 7, 1233-1238.

[7] Zhang, K., DAI, L., Wu, M., Zeng, T., YuAn, M., ChEn, Y. 2020. «Women's experience of psychological birth trauma in China: a qualitative study». BMC Pregnancy and Childbirth, 20, 651.

[8] FIELD, T. 2018. «Postnatal anxiety prevalence, predictors and effects on development: A narrative review». Infant Behav Dev, 51, 24-32.

[9] Jenabi, E., Khazaei, S., Bashirian, S., Aghababaei, S., Matinnia, N. 2020. «Reasons for elective cesarean section on maternal request: a systematic review». J Matern Fetal Neonatal Med., 33, 3867-3872.

[10] Bringedal, H., Aune, I. 2019. «Able to choose? Women's thoughts and experiences regarding informed choices during birth». Midwifery, 77, 123-129.

[11] IIDA, M., HoriUCHI, S., NAGAMORI, K. 2020. «Women's experience of receiving team-midwifery care in Japan: A qualitative descriptive study». Women Birth, 8, S1871-5192(20)30338-3 3-9.

[12] Aannestad, M., Herstad, M., Severinsson, E. 2020. «A meta-ethnographic synthesis of qualitative research on women's experience of midwifery care». Nursing and Health Sciences, 22, 171-183.

[13] Hildingsson, I., Rubertsson, C. 2021. «The role of women's emotional profiles in birth outcome and birth experience». J Psychosom Obstet Gynaecol, 15,1-9.

[14] Contes, D., Thirukumar, P., Spear, V., Brown, G., Henry, A. 2020. «What are women's mode of birth preferences and why? A systematic scoping review». Women Birth, 33, 323-333.

[15] Striebich, S., Ayerle, G. 2020. «Fear of childbirth (FOC): pregnant women's perceptions towards the impending hospital birth and coping resources - a reconstructive study». J Psychosom Obstet Gynaecol, 41, 231-239.

[16] Wigert, H., Nilsson, C., Dencker, A., Begley, C., Jangsten, E., SparudLundin, C., Mollberg, M., Patel, H. 2020. «Women's experiences of fear of childbirth: a metasynthesis of qualitative studies». Int J Qual Stud Health Well-being, 15, 1704484.

[17] SERÇEKUŞ, P., VARDAR, O., ÖZKAN, S. 2020. «Fear of childbirth among pregnant women and their partners in Turkey». Sex Reprod Healthc, 24, 100501. 
[18] Sheen, K., Slade, P. 2018. «Examining the content and moderators of women's fears for giving birth: A meta-synthesis». J Clin Nurs, 27, 25232535 .

[19] Byrne, V., Egan, J., Neela, P. Mac, Sarma, K. 2017. «What about me? The loss of self through the experience of traumatic childbirth». Midwifery, $\mathbf{5 1}, 1-11$.

[20] Vasilachis de Gialdino, I. 2006. Estrategias de Investigación Cualitativa. Gedisa, Bartzelona.

[21] Burns, N., Grove, S. K. 2016. Investigación En Enfermería : Desarrollo de La Práctica Enfermera Basada En La Evidencia. Elsevier Health Sciences Spain, Bartzelona.

[22] Pedraz Marcos, A., Zarco Colón, J., Ramasco Gutiérrez, M., Palmar Santos, A. M., SAntos, A. M. P. 2014. Investigación Cualitativa. Elsevier, Bartzelona.

[23] Miles, M. B., Huberman, A. M., Saldaña, J. 2020. Qualitative Data Analysis : A Methods Sourcebook. SAGE Publications Ltd, Londres.

[24] Hernández Sampieri, R., Fernández Collado, C., Baptista Lucio, P. 2014. Metodología de La Investigación. McGraw-Hill Education, Mexiko.

[25] Valles, M. S. 2000. Técnicas Cualitativas de Investigación Social: Reflexión Metodológica y Práctica Profesional. Síntesis, Madril.

[26] Holloway, I., Galvin, K. 2016. Qualitative Research in Nursing and Healthcare. Wiley Blackwell, Chichester.

[27] Calderón, C. 2009. Assessing the Quality of Qualitative Health Research: Criteria, Process and Writing [49 paragrafoak]. Forum Qualitative Sozialforschung / Forum Qualitative Research, 10 (2), Art. 17.

[28] Dencker, A., Nilsson, C., Begley, C., Jangsten, E., Mollberg, M., PAtel, H., Wigert, H., Hessman, E., Sjöblom, H., Sparud-Lundin, C. 2019. «Causes and outcomes in studies of fear of childbirth: A systematic review». Women Birth, 32, 99-111.

[29] Rilby, L., Jansson, S., Lindblom, B., MÅrtensson, L. B. 2012. «A Qualitative Study of Women's Feelings About Future Childbirth: Dread and Delight». J Midwifery Women's Health, 57, 120-125.

[30] Slade, P., Balling, K., Sheen, K., Houghton, G. 2019. «Establishing a valid construct of fear of childbirth: Findings from in-depth interviews with women and midwives». BMC Pregnancy and Childbirth, 19,96.

[31] Karlström, A., Nystedt, A., Hildingsson, I. 2015. «The meaning of a very positive birth experience: focus groups discussions with women». $B M C$ Pregnancy and Childbirth, 15, 251.

[32] O’Brien, D., Butler, M. M., CASEy, M. 2017. «A participatory action research study exploring women's understandings of the concept of informed choice during pregnancy and childbirth in Ireland». Midwifery, 46, 1-7. 